\title{
The effect of uncouplers of oxidative phosphorylation on the feeding behavior of lactating dairy cows
}

\author{
Katherine M. Kennedy and Michael S. Allen* \\ Department of Animal Science, Michigan State University, East Lansing 48824
}

\section{ABSTRACT}

Our objective was to determine the effects of uncouplers of oxidative phosphorylation on feeding behavior of lactating dairy cows. We hypothesized that uncouplers of oxidative phosphorylation would increase meal size and meal length and performed 2 experiments to test our hypothesis. In experiment 1, 4 late-lactation cows $(345 \pm 48.4 \mathrm{~d}$ in milk; mean $\pm \mathrm{SD})$ were administered a daily intrajugular injection of either 10 $\mathrm{mg} / \mathrm{kg}$ of $\mathrm{BW}^{0.75}$ of 2,4-dinitrophenol methyl ether (DNPME) and propylene carbonate or propylene carbonate (control; CON) in a crossover design with 2 -d periods. In experiment 2, 8 early-lactation cows (11.3 $\pm 0.89 \mathrm{~d}$ in milk) were administered a daily intrajugular injection via jugular catheter of either $50 \mathrm{mg} / \mathrm{kg}$ of BW of sodium salicylate (SAL) and saline or saline (control; CON) in a crossover design with 1-d periods. Feeding behavior was recorded by a computerized data acquisition system and analyzed for the first $4 \mathrm{~h}$ after access to feed within $15 \mathrm{~min}$ of treatment for both experiments. Neither DNPME nor SAL affected meal size over the first $4 \mathrm{~h}$ after access to feed. However, DNPME increased meal length by $6.4 \mathrm{~min}$ (26.3 vs. $19.9 \mathrm{~min}$ ) and tended to decrease the number of meals ( 2.55 vs. 2.78 meals $/ 4 \mathrm{~h}$ ) over the first $4 \mathrm{~h}$ after access to feed compared with CON. Both DNPME and SAL decreased eating rate over the first $4 \mathrm{~h}$ after access to feed compared with their respective controls (0.10 vs. $0.12 \mathrm{~kg} / \mathrm{min}$ for DNPME vs. CON; 0.06 vs. $0.07 \mathrm{~kg} /$ min for SAL vs. CON). Lack of treatment effects on meal size may have been caused by increased rate of oxidation of fuels compensating for the disruption of oxidative phosphorylation.

Key words: hepatic oxidation, feeding behavior, uncoupler, oxidative phosphorylation

Received March 4, 2019

Accepted July 2, 2019.

*Corresponding author: allenm@msu.edu

\section{INTRODUCTION}

Understanding the control of feed intake in dairy cows is critical to optimize milk yield and efficiency of production. Although multiple controls of intake act simultaneously at any given moment, the dominant mechanisms controlling feed intake change with physiological states across lactation (Allen, 2014). Metabolic mechanisms likely dominate control of feed intake for dairy cows in the immediate postpartum $(\mathbf{P P})$ period (first $3 \mathrm{wk}$ of lactation) that are in a lipolytic state as well as cows in late lactation in positive energy balance, whereas ruminal distention likely limits feed intake for high-producing cows in early and mid lactation (Allen and Piantoni, 2013). Allen et al. (2009) proposed that feed intake in the immediate PP period is controlled by the oxidation of various fuels in the liver, which they called the hepatic oxidation theory. Studies in rodents have shown that feeding behavior is related to hepatic energy status (Rawson et al., 1994; Friedman et al., 1999). Furthermore, a change in hepatic energy status, and not a change in ATP concentration alone, is likely necessary for this mechanism to influence feed intake (Ji et al., 2000).

Two well-studied synthetic uncouplers of oxidation phosphorylation (OXPHOS) are 2,4-dinitrophenol (DNP) and salicylate. These uncouplers are protonophores that decrease ATP synthesis by decreasing the proton-motive force necessary for ATP synthesis by the electron transport chain. Uncouplers administered systemically can increase heat production (Hoch and Hogan, 1973; Grundlingh et al., 2011), possibly decreasing appetite. However, when fed to broilers at a dose of 100 $\mathrm{mg} / \mathrm{kg}$, DNP increased feed intake (Toyomizu et al., 1992), consistent with the hepatic oxidation theory. No research has examined the effect of DNP on feed intake in any ruminant model. Recently, Perry et al. (2013) showed that DNP methyl ether (DNPME) is preferentially extracted by the liver and subsequently converted to DNP, which allows for liver-focused experiments.

Intramuscular administration of lysine acetylsalicylate increased DMI of cows in the immediate PP period (Bertoni et al., 2004). Oral administration of salicylate 
to cows in the immediate PP period (first 3 DIM) increased meal length and decreased meal frequency beginning at wk 10 of lactation, but feeding behavior was not analyzed for the individual days that treatment was administered (Carpenter et al., 2018). Our objective was to determine the short-term effects of uncouplers of OXPHOS on feeding behavior in lactating dairy cows. We hypothesized that uncouplers of OXPHOS would increase meal size and length, possibly increasing DMI.

\section{MATERIALS AND METHODS}

The Institutional Animal Care and Use Committee at Michigan State University approved all experimental procedures for this experiment.

\section{Animals, Housing, and Diets}

Two experiments were conducted to evaluate the effects of uncouplers of OXPHOS on the feeding behavior of lactating cows.

Experiment 1. Four nonpregnant cows in late lactation at $345 \pm 48.4 \mathrm{DIM}($ mean $\pm \mathrm{SD})$ with mean $( \pm \mathrm{SD})$ milk yield of $32.3 \pm 1.33 \mathrm{~kg} / \mathrm{d}$, BCS of $3.92 \pm 0.24$, and $\mathrm{BW}$ of $831 \pm 13.7 \mathrm{~kg}$ were used to evaluate the effects of DNPME. Cows were fed a TMR once daily at $110 \%$ of expected intake and received a common experimental diet throughout the experiment. Diet DM percentage was determined daily by drying TMR samples at $55^{\circ} \mathrm{C}$ in a forced-air oven for $72 \mathrm{~h}$. The ration was formulated to contain $32 \% \mathrm{NDF}, 19 \%$ forage NDF, $28 \%$ starch, and $17 \% \mathrm{CP}$ on a DM basis and consisted of corn silage, dry ground corn, dried corn gluten feed, alfalfa silage, mixed alfalfa-grass silage, cotton seeds, high-moisture corn, soybean hulls, SoyPlus (Landus Cooperative, Ames, IA), wheat straw, and a premix of protein supplement, minerals, and vitamins (Table 1). Cows were fed a relatively high-starch ration, and control of feed intake was expected to be dominated by metabolic mechanisms.

Experiment 2. Eight cows in the immediate PP period at $11.3 \pm 0.89 \mathrm{DIM}$ (mean $\pm \mathrm{SD}$ ) with mean $( \pm \mathrm{SD})$ milk yield of $40.5 \pm 5.18 \mathrm{~kg} / \mathrm{d}$, BCS of $3.13 \pm$ 0.21 , and $\mathrm{BW}$ of $749 \pm 58.8 \mathrm{~kg}$ were used to evaluate the effects of sodium salicylate. Cows were fed a TMR once daily at $110 \%$ of expected intake and received a common experimental diet throughout the experiment. Diet DM percentage was determined daily by drying TMR samples at $55^{\circ} \mathrm{C}$ in a forced-air oven for $72 \mathrm{~h}$. The ration was formulated to contain $28 \% \mathrm{NDF}, 23 \%$ forage NDF, $25 \%$ starch, and $18.5 \% \mathrm{CP}$ on a DM basis and consisted of corn silage, alfalfa silage, alfalfa hay, dry ground corn, soybean meal, soybean hulls, and a premix of protein supplement, minerals, and vitamins (Table 1).

\section{Experimental Design and Treatments}

Experiment 1. A crossover design with 2-d periods and $3 \mathrm{~d}$ of rest between periods to minimize carryover effects of treatment was used. The half-life of DNP has been reported to range from approximately 1 to $4 \mathrm{~h}$ in mice and rats (USEPA, 1980). We included $3 \mathrm{~d}$ of rest between treatment periods to be conservative because DNPME had not been used in ruminants. The experiment was completed during May 2017. Treatments consisted of an intrajugular injection of either $10 \mathrm{mg} / \mathrm{kg}$ of $\mathrm{BW}^{0.75}$ of DNPME (DNPME treatment; Alfa Aesar, Tewksbury, MA; B21542) in propylene carbonate (2:1 ratio of propylene carbonate to DNPME on a pergram basis, Sigma-Aldrich, St. Louis, MO; 310328) or propylene carbonate alone (control treatment; CON) approximately 15 min before daily feed access on each day within a period. Treatment dose was selected based on Perry et al. (2013), who administered an intraperitoneal injection dose of $5 \mathrm{mg} / \mathrm{kg}$ DNPME into rats. To

Table 1. Ingredients and nutrient composition of experimental diet for experiments 1 and 2 (\% of dietary DM except for DM)

\begin{tabular}{lcc}
\hline Item & Experiment 1 & Experiment 2 \\
\hline Ingredient & & \\
Corn silage & 25.9 & 30.3 \\
Ground corn & 16.7 & 19.3 \\
Corn gluten feed & 16.6 & - \\
Alfalfa silage & 9.1 & 15.4 \\
Alfalfa grass silage & 9.1 & - \\
Alfalfa hay & - & 11.3 \\
Cottonseed & 7.2 & - \\
High-moisture corn & 6.0 & - \\
Vitamin and mineral mix ${ }^{2}$ & 4.4 & 4.2 \\
Soybean hulls & 2.2 & 2.5 \\
SoyPlus & 2.1 & - \\
Wheat straw & 0.6 & \\
Nutrient composition & & \\
DM (\%) & 48.6 & 55.7 \\
OM & 92.2 & 90.9 \\
Starch & 27.6 & 25.1 \\
NDF & 32.1 & 27.7 \\
Forage NDF & 19.0 & 23.0 \\
CP & 17.0 & 18.5 \\
\hline
\end{tabular}

${ }^{1}$ Vitamin and mineral mix for experiment 1 contained $21.9 \%$ urea (45\%), $11.7 \% \mathrm{NaCl}, 10.4 \% \mathrm{Ca}, 0.91 \% \mathrm{Mg}, 0.91 \% \mathrm{P}, 9.3 \% \mathrm{Na}, 14 \mathrm{mg} /$ $\mathrm{kg} \mathrm{Co}, 232 \mathrm{mg} / \mathrm{kg} \mathrm{Cu}, 9.1 \mathrm{mg} / \mathrm{kg} \mathrm{I}, 1,275 \mathrm{mg} / \mathrm{kg} \mathrm{Fe}, 995 \mathrm{mg} / \mathrm{kg} \mathrm{Mn}$, $6.9 \mathrm{mg} / \mathrm{kg} \mathrm{Se}, 1,016 \mathrm{mg} / \mathrm{kg} \mathrm{Zn}, 28.3 \mathrm{kIU} / \mathrm{kg}$ vitamin A, $4.7 \mathrm{kIU} / \mathrm{kg}$ vitamin $\mathrm{D}$, and $142 \mathrm{IU} / \mathrm{kg}$ vitamin $\mathrm{E}$. Vitamin and mineral mix for experiment 2 contained $11.4 \% \mathrm{NaCl}, 12.8 \% \mathrm{Ca}, 0.99 \% \mathrm{Mg}, 0.99 \% \mathrm{P}$, $10.9 \% \mathrm{Na}, 14 \mathrm{mg} / \mathrm{kg} \mathrm{Co}, 250 \mathrm{mg} / \mathrm{kg} \mathrm{Cu}, 9.9 \mathrm{mg} / \mathrm{kg} \mathrm{I}, 745 \mathrm{mg} / \mathrm{kg} \mathrm{Fe}$, $994 \mathrm{mg} / \mathrm{kg} \mathrm{Mn}, 7.5 \mathrm{mg} / \mathrm{kg}$ Se, $1,093 \mathrm{mg} / \mathrm{kg} \mathrm{Zn}, 30.6 \mathrm{kIU} / \mathrm{kg}$ vitamin $\mathrm{A}, 5.1 \mathrm{kIU} / \mathrm{kg}$ vitamin $\mathrm{D}$, and $152 \mathrm{IU} / \mathrm{kg}$ vitamin $\mathrm{E}$.

${ }^{2}$ Landus Cooperative, Ames, IA. 
challenge the cows, we doubled the dose to $10 \mathrm{mg} / \mathrm{kg}$ of $\mathrm{BW}^{0.75}$, equivalent to approximately $2 \mathrm{mg} / \mathrm{kg}$.

Experiment 2. A crossover design with 1-d periods and $1 \mathrm{~d}$ of rest between each period to minimize carryover effects was used. The half-life of salicylate in cattle is $50 \mathrm{~min}$ (Short et al., 1991), so a day of rest between treatments was adequate for clearance. Animals were blocked based on parturition date, and each block consisted of 4 cows. Block 1 was completed during July 2017, and block 2 was completed during August 2017. Treatments consisted of an intrajugular injection of either $50 \mathrm{mg} / \mathrm{kg}$ of BW of sodium salicylate (SAL treatment; Sigma-Aldrich; S2679) in 0.9\% saline (USP grade, 2:1 ratio of saline to sodium salicylate on a per-gram basis) or saline alone (control treatment; CON) via jugular catheter approximately $15 \mathrm{~min}$ before daily feed access. Treatment dose of sodium salicylate $(\sim 37.5 \mathrm{~g} / \mathrm{d})$ provided approximately $32 \mathrm{~g}$ of salicylate, which was approximately $30 \%$ of the $125 \mathrm{~g} / \mathrm{d}$ oral dose administered by Carpenter et al. (2018) but much more than the approximately $6 \mathrm{~g}$ of salicylate provided by the $15 \mathrm{~g} / \mathrm{d}$ dose of lysine acetylsalicylate administered intramuscularly by Bertoni et al. (2004) for the first 3 DIM.

\section{Data and Sample Collection}

Experiment 1. Cows were blocked from feed from 0800 to $1000 \mathrm{~h}$ daily, and the amount of feed offered and orts were weighed for each cow daily. Samples (0.5 $\mathrm{kg})$ of the TMR were collected daily, and orts $(\sim 0.5 \mathrm{~kg})$ were sampled for each cow and stored in plastic bags at $-20^{\circ} \mathrm{C}$ until processed. Feeding behavior was monitored continuously for $22 \mathrm{~h}$ posttreatment for each cow with a computerized data acquisition system (Dado and Allen, 1995) except when cows were milked in the parlor. Feed disappearance and water consumption were recorded for each cow every $5 \mathrm{~s}$, and meal size, interval between meals, and meal frequency were calculated. Hunger ratio was calculated as the weight of meal divided by premeal interval, and satiety ratio was calculated as the weight of meal divided by postmeal interval (Forbes, 2007). Eating rate was calculated as meal size divided by meal length.

Cows were milked twice daily at 0530 and $1730 \mathrm{~h}$ in a milking parlor. Milk yield was recorded daily at each milking, and milk samples were collected from each milking during the treatment periods and stored with preservative (Bronopol tablet; D\&F Control Systems, San Ramon, CA) at $4^{\circ} \mathrm{C}$. Milk samples were analyzed for fat, true protein, lactose, and MUN by mid-infrared spectroscopy (AOAC International, 1997) by the Michigan Herd Improvement Association (Universal Lab Services, East Lansing, MI).
Blood was collected from the coccygeal vessel at -1 and $4 \mathrm{~h}$ relative to access to feed at $1000 \mathrm{~h}$ on $\mathrm{d}$ 1 and 2 of each period. Blood samples were collected into 3 tubes containing $\mathrm{K}_{2}$ EDTA and 1 tube containing potassium oxalate with $\mathrm{NaF}$ as a glycolytic inhibitor (Vacutainer tubes, VWR, Radnor, PA) and placed on ice until centrifugation. Tubes were centrifuged at $1,700 \times g$ for $15 \mathrm{~min}$ at $4^{\circ} \mathrm{C}$ immediately after sample collection. Plasma was harvested and frozen at $-20^{\circ} \mathrm{C}$ until analysis. Liver samples $(\sim 200 \mathrm{mg})$ were biopsied as described by Bradford and Allen (2005) at -1 and $4 \mathrm{~h}$ relative to access to feed at $1000 \mathrm{~h}$ on $\mathrm{d} 1$ and 2 of each period. Liver samples were flash frozen in liquid nitrogen, stored on dry ice for transportation, and then stored at $-80^{\circ} \mathrm{C}$ until further analysis.

Experiment 2. Data and sample collection were the same as listed in experiment 1 except blood was collected from a jugular catheter and treatment periods were $1 \mathrm{~d}$. Cows were fitted with jugular catheters $2 \mathrm{~d}$ before the start of the experiment, and catheters were maintained by flushing the lines twice daily with approximately $5 \mathrm{~mL}$ of sterile $3.5 \%$ sodium citrate solution. Blood was collected from the catheter at -1 and $4 \mathrm{~h}$ relative to opening of feed gates at $1000 \mathrm{~h}$. Liver samples $(\sim 200 \mathrm{mg})$ were biopsied as described by Bradford and Allen (2005) at -1 and $4 \mathrm{~h}$ relative to access to feed at $1000 \mathrm{~h}$. Liver samples were flash frozen in liquid nitrogen, stored on dry ice for transportation, and then stored at $-80^{\circ} \mathrm{C}$ until further analysis.

\section{Analysis of Samples}

Analyses of samples were the same for both experiments. Commercial kits were used to determine concentrations of nonesterified fatty acids (NEFA; NEFA HR kit, Wako Chemicals USA, Richmond, VA), BHB (kit no. 2240, Stanbio Laboratory, Boerne, TX), and BUN (kit no. EIABUN, Thermo Fisher Scientific, Waltham, MA). Glucose was determined using a glucose oxidase method (Sigma-Aldrich). The above metabolites were analyzed colorimetrically with a microplate reader (SpectraMax Plus 384, Molecular Devices, San Jose, CA) to determine their plasma concentrations. Insulin concentration was determined using a bovine insulin ELISA kit (kit no. 10-1201-01, Mercodia, Uppsala, Sweden).

Liver samples were analyzed for citrate, isocitrate, succinate, fumarate, malate, pyruvate, lactate, BHB, glutamate, aspartate, oxaloacetate, $\alpha$-ketoglutarate, phosphate, glucose, $\gamma$-aminobutyric acid, DNP, and salicylate by GC-MS and for coenzyme A (CoA), acetyl CoA, propionyl CoA, succinyl CoA, and methylmalonyl CoA by liquid chromatography-tandem MS. Liver samples were analyzed and quantified as described by 
Kennedy and Allen (2019) except the homogenizing solvent was 1\% formic acid in 70\% acetonitrile: $30 \%$ $\mathrm{H}_{2} \mathrm{O}$. The retention time of DNP was 11.7 min and was monitored at 195.1 and $241.1 \mathrm{~m} / z$ (mass:charge ratio). The retention time of salicylate was $11.0 \mathrm{~min}$ and was monitored at 309.1 and $351.2 \mathrm{~m} / \mathrm{z}$.

\section{Statistical Analysis}

All data were analyzed using PROC MIXED of SAS software (version 9.4, SAS Institute Inc., Cary, NC) with repeated measures. Before statistical analysis, Box-Cox transformation analyses were applied to each response variable to determine necessary transformations on the data using JMP Pro (version 13.2, SAS Institute Inc.). Due to the short half-life of DNP ( $\sim 1$ to $4 \mathrm{~h}$ in mice and rats; USEPA, 1980) and salicylate (50 min in cattle; Short et al., 1991), feeding behavior was statistically analyzed for the first $4 \mathrm{~h}$ relative to access to feed and for the first meal relative to access to feed.

Experiment 1. Feeding behavior for the first meal and for the first $4 \mathrm{~h}$ relative to access to feed were analyzed with cow as a random effect and the fixed effects of treatment, day, period, and all associated interactions. Day was used in the repeated statement to account for repeated measures, and the subject was defined as cow $\times$ period interaction. Milk yield and milk components were analyzed with cow as a random effect and the fixed effects of treatment, sampling time, period, and all associated interactions. Baseline morning and afternoon samples taken $1 \mathrm{~d}$ before the start of the experiment were used as a covariate in the model. Time was used in the repeated statement to account for repeated measures, and the subject was defined as cow $\times$ period interaction. Plasma metabolites over time were analyzed with cow as a random effect, the $-1 \mathrm{~h}$ sampling time point as a covariate, and the fixed effects of treatment, day, sampling time, period, and all associated interactions. Time and day were used in the repeated statement to account for repeated measures, and the subject was defined as cow $\times$ period interaction. Liver samples were analyzed using the same model except with run and cow within run as random effects, and the subject was defined as cow nested within run $\times$ period interaction in the repeated statement. Run was defined as the group of samples analyzed on a mass spectrometer (GC-MS or liquid chromatography-tandem MS) within a single session.

Experiment 2. Feeding behavior for the first meal and for the first $4 \mathrm{~h}$ relative to access to feed was analyzed with block and cow within block as random effects and the fixed effects of treatment, period, and treatment $\times$ period interaction. Milk yield and milk components data over time were analyzed with block and cow within block as random effects and the fixed effects of treatment, sampling time, period, and all associated interactions. Baseline morning and afternoon samples taken $1 \mathrm{~d}$ before the start of the experiment were used as a covariate in the model. Time was used in the repeated statement to account for repeated measures, and the subject was defined as cow nested within block $\times$ period interaction. Liver and plasma data over time were analyzed with block and cow within block as random effects, the $-1 \mathrm{~h}$ sampling time point as a covariate, and the fixed effects of treatment, sampling time, period, and all associated interactions. Time was used in the repeated statement to account for repeated measures, and the subject was defined as cow nested within block $\times$ period interaction.

Both Experiments. The covariance structure was either compound symmetry or first-order Toeplitz for all analytes in experiments 1 and 2 based on Bayesian information criterion score. Denominator degrees of freedom were estimated using the Kenward-Roger option in the MODEL statement. Paired differences were determined using the diff option in PROC MIXED. Treatment effects and interactions were declared at $P$ $\leq 0.05$, and tendencies for treatment effects were declared at $P \leq 0.10$. Data transformed are noted in the tables and figures along with the transformation used for statistical analysis. All transformed data have been back-transformed for interpretation.

\section{RESULTS}

\section{Feed Intake and Feeding Behavior}

Experiment 1. The DNPME treatment did not affect daily DMI compared with CON (28.6 vs. 28.7 $\mathrm{kg} / \mathrm{d} ; P=0.82$; Table 2 ) but decreased eating rate compared with CON for the first meal after access to feed within $15 \mathrm{~min}$ of treatment $(0.10$ vs. $0.15 ; P=$ $0.03)$ and over the first $4 \mathrm{~h}$ after access to feed (0.10 vs. $0.12 \mathrm{~kg} / \mathrm{min} ; P=0.01)$. The DNPME treatment also increased meal length (26.3 vs. $19.9 \mathrm{~min} / \mathrm{meal} ; P=$ $0.05)$ and number of drink bouts (2.33 vs. 1.49 drinks $/ 4$ h; $P=0.03)$ and tended to decrease drink size $(12.3$ vs. $15.6 \mathrm{~L} /$ drink; $P=0.09$ ) compared with $\mathrm{CON}$ over the first $4 \mathrm{~h}$ after access to feed. In addition, DNPME decreased the number of meal bouts compared with CON on $d 1$ but only tended to decrease the number of meal bouts over both days (Figure 1; interaction, $P=$ 0.04). Feeding behavior was also examined from 4 to 8 $\mathrm{h}$ after access to feed, but no significant treatment or treatment $x$ day interactions were observed (data not shown; $P>0.10)$. 
Experiment 2. The SAL treatment did not affect daily DMI compared with CON (17.4 vs. $18.0 \mathrm{~kg} ; P$ $=0.56)$, nor did SAL have any effects on meal length, meal size, eating rate, or eating interval for the first meal after access to feed (Table $3 ; P>0.10$ ). However, SAL decreased eating rate compared with $\mathrm{CON}$ over the first $4 \mathrm{~h}$ after access to feed $(0.06$ vs. $0.07 \mathrm{~kg} / \mathrm{min}$; $P=0.04)$ but had no other effects on feeding behavior. Feeding behavior was also examined from 4 to $8 \mathrm{~h}$ after access to feed, and eating interval tended to increase with SAL compared with CON (102 vs. $69.9 \mathrm{~min} ; P$ $=0.08)$, but no other treatment effects were observed.

\section{Milk Production and Components}

Experiment 1. The DNPME treatment tended to decrease milk fat concentration (3.89 vs. $4.16 \% ; P=$ 0.10 ) and tended to increase MUN yield (2.45 vs. 2.19 $\mathrm{g} ; P=0.10)$ compared with $\mathrm{CON}$ for the first milking after treatment (afternoon) and decreased milk protein concentration compared with $\mathrm{CON}$ in the second (morning) milking after treatment (3.36 vs. $3.44 \% ; P=$ 0.02; Appendix Table A1).

Experiment 2. The SAL treatment did not affect milk yield or components for the first (afternoon) milk- ing after treatment $(P>0.10)$, tended to decrease milk yield (20.6 vs. $22.7 \mathrm{~kg} ; P=0.07)$ and milk lactose yield (1.33 vs. $1.48 \mathrm{~kg} ; P=0.10)$, and decreased fat yield $(1.32$ vs. $1.49 \mathrm{~kg} ; P=0.05)$ and protein yield $(0.88$ vs. $0.99 \mathrm{~kg} ; P=0.05)$ compared with CON for the second (morning) milking after treatment (Appendix Table A2).

\section{Plasma and Liver Metabolites}

Experiment 1. Plasma metabolite and hormone concentrations were not affected by treatment (Appendix Table A3). The DNPME treatment increased hepatic DNP concentration from 2.76 to $9.67 \mathrm{nmol} / \mathrm{g}$ compared with CON (2.49 to $2.55 \mathrm{nmol} / \mathrm{g}$; interaction, $P=0.03$; Table 4) and tended to increase hepatic CoA concentration and hepatic acetyl CoA concentration on d 1 compared with CON (Figure 2; pairwise tests, $P$ $\leq 0.10)$. An interaction of treatment, day, and sampling time was detected for acetyl CoA concentration (interaction, $P=0.05$ ); however, pairwise effects were detected only for d 2 (Figure 3 ). Although a numerical increase in hepatic acetyl CoA concentration from $-1 \mathrm{~h}$ to $4 \mathrm{~h}$ on $\mathrm{d} 2$ for CON was observed, this increase was not significant (pairwise test, $P=0.20$ ). The DNPME

Table 2. Effect of an intrajugular injection of $10 \mathrm{mg} / \mathrm{kg}$ of $\mathrm{BW}^{0.75}$ of 2,4-dinitrophenol methyl ether and propylene carbonate (DNPME) or propylene carbonate (control) on feeding behavior for the first meal after access to feed and on feeding behavior over the first $4 \mathrm{~h}$ after access to feed in dairy cows for experiment 1

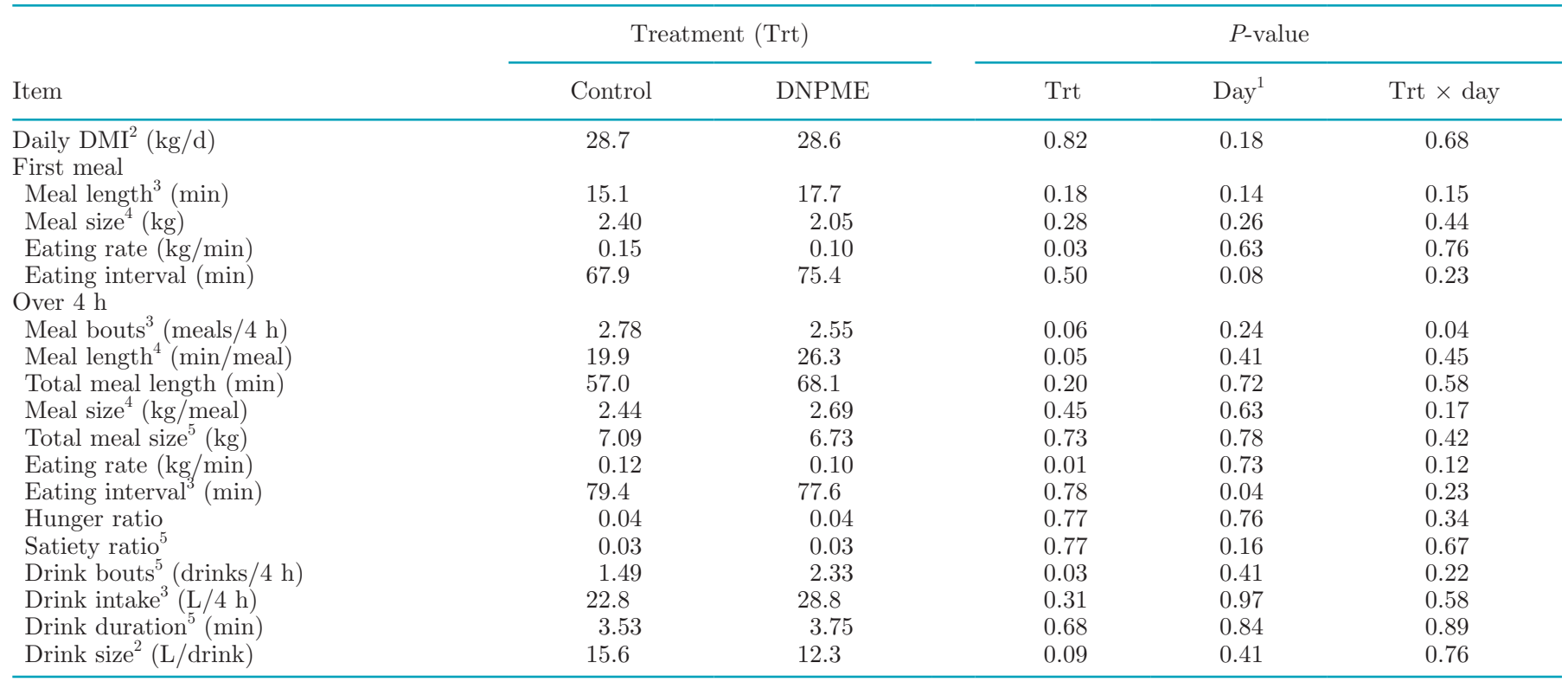

${ }^{1}$ Each period in the crossover design consisted of $2 \mathrm{~d}$.

${ }^{2}$ Data were transformed using the reciprocal for statistical analysis and back-transformed for interpretation purposes.

${ }^{3}$ Data were transformed using the inverse of the square root for statistical analysis and back-transformed for interpretation purposes.

${ }^{4}$ Data were transformed using the square root for statistical analysis and back-transformed for interpretation purposes.

${ }^{5}$ Data were log-transformed for statistical analysis and back-transformed for interpretation purposes. 
treatment increased hepatic lactate concentration compared with $\mathrm{CON}$ on d 2 but not over both days (Figure $2 \mathrm{C}$; interaction, $P=0.05)$ and tended to increase mean hepatic inorganic phosphate concentrations compared with CON (6,097 vs. $4,494 \mathrm{nmol} / \mathrm{g} ; P=0.08)$. The DNPME treatment also tended to decrease mean hepatic aspartate concentrations compared with $\mathrm{CON}$ (263 vs. $336 \mathrm{nmol} / \mathrm{g} ; P=0.08)$ and decreased aspartate concentration compared with CON on d 1 but not over both days (Figure 2D; interaction, $P=0.05$ ).

Experiment 2. Plasma metabolite and hormone concentrations were not affected by treatment (Appendix Table A4). The SAL treatment increased hepatic salicylate concentration from 12.8 to $19.9 \mathrm{nmol} / \mathrm{g}$ compared with CON (13.8 to $12.6 \mathrm{nmol} / \mathrm{g}$; interaction, $P$ $<0.01$; Table 5), increased mean CoA (6.78 vs. 5.64 $\mathrm{nmol} / \mathrm{g} ; P=0.04)$ and mean acetyl CoA (2.62 vs. 2.25 $\mathrm{nmol} / \mathrm{g} ; P=0.03)$ concentrations, and tended to increase mean succinyl CoA concentrations (4.76 vs. 4.04 $\mathrm{nmol} / \mathrm{g} ; P=0.07)$ compared with $\mathrm{CON}$.

Table 3. Effect of an intrajugular injection of $50 \mathrm{mg} / \mathrm{kg}$ of BW of sodium salicylate and saline (SAL) or saline (control) on feeding behavior for the first meal after access to feed and on feeding behavior over the first $4 \mathrm{~h}$ of feeding in dairy cows for experiment 2

\begin{tabular}{|c|c|c|c|}
\hline \multirow[b]{2}{*}{ Item } & \multicolumn{2}{|c|}{ Treatment } & \multirow{2}{*}{$\frac{P \text {-value }}{\text { Treatment }}$} \\
\hline & Control & SAL & \\
\hline Daily $\mathrm{DMI}^{1}(\mathrm{~kg} / \mathrm{d})$ & 18.0 & 17.4 & 0.56 \\
\hline \multicolumn{4}{|l|}{ First meal } \\
\hline Meal length (min) & 33.2 & 31.5 & 0.81 \\
\hline Meal size (kg) & 2.83 & 2.55 & 0.69 \\
\hline 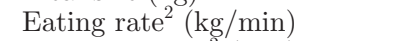 & 0.09 & 0.08 & 0.45 \\
\hline Eating interval $^{2}(\min )$ & 69.0 & 82.4 & 0.40 \\
\hline \multicolumn{4}{|l|}{ Over $4 \mathrm{~h}$} \\
\hline Meal bouts ${ }^{3}$ (meals/d) & 2.48 & 2.29 & 0.43 \\
\hline Meal length ${ }^{2}(\mathrm{~min} / \mathrm{meal})$ & 31.2 & 36.9 & 0.28 \\
\hline Total meal length ${ }^{3}(\min )$ & 78.4 & 79.7 & 0.87 \\
\hline Meal size $^{4}(\mathrm{~kg} /$ meal $)$ & 2.00 & 1.85 & 0.55 \\
\hline Total meal size $(\mathrm{kg})$ & 5.33 & 4.43 & 0.13 \\
\hline Eating rate $(\mathrm{kg} / \mathrm{min})$ & 0.07 & 0.06 & 0.04 \\
\hline Eating interval $^{5}$ (min) & 71.1 & 86.0 & 0.22 \\
\hline Hunger ratio $^{2}$ & 0.02 & 0.02 & 0.79 \\
\hline Satiety ratio ${ }^{4}$ & 0.03 & 0.02 & 0.51 \\
\hline Drink bouts $^{2}$ (drinks/d) & 4.22 & 4.17 & 0.94 \\
\hline Drink intake (L/d) & 25.5 & 25.5 & 0.99 \\
\hline Drink duration $^{5^{\prime}}$ (min/drink) & 2.88 & 2.93 & 0.90 \\
\hline $\operatorname{Drink} \operatorname{size}^{3}(\mathrm{~L} /$ drink $)$ & 5.91 & 5.84 & 0.91 \\
\hline
\end{tabular}

${ }^{1}$ Data were transformed using the square for statistical analysis and back-transformed for interpretation purposes.

${ }^{2}$ Data were transformed using the square root for statistical analysis and back-transformed for interpretation purposes.

${ }^{3}$ Data were transformed using the reciprocal for statistical analysis and back-transformed for interpretation purposes.

${ }^{4}$ Data were transformed using the inverse of the square root for statistical analysis and back-transformed for interpretation purposes.

${ }^{5}$ Data were log-transformed for statistical analysis and back-transformed for interpretation purposes.

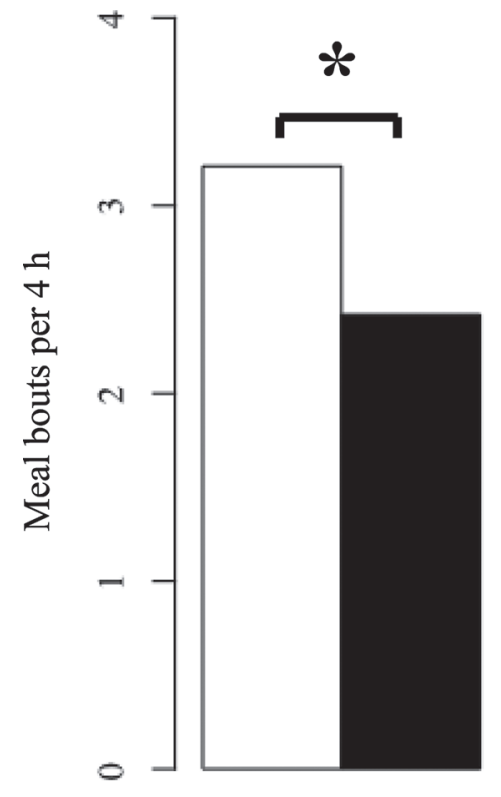

Day 1

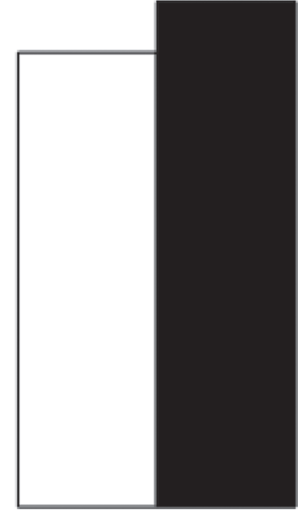

Day 2
Figure 1. Number of meal bouts over the first $4 \mathrm{~h}$ following access to feed on $\mathrm{d} 1$ and 2 from experiment 1 . Treatments were an intrajugular injection of $10 \mathrm{mg} / \mathrm{kg}$ of $\mathrm{BW}^{0.75}$ of 2,4-dinitrophenol methyl ether and propylene carbonate (black) or propylene carbonate (control; white). The control treatment decreased meal bouts on d 2 compared with d $1(P=0.03)$. Data were transformed with the inverse square root for statistical analysis and back-transformed for interpretation. Within-day differences are denoted by $*(P<0.05)$.

\section{DISCUSSION}

\section{Experiment 1}

The increase in DNP concentration at $4 \mathrm{~h}$ relative to baseline confirms that DNPME was absorbed and processed by the liver. Our hepatic DNP concentrations were similar to those reported in Perry et al. (2013). We did not observe an increase in meal size as expected with the DNPME treatment. However, we did observe an increase in meal length over the first $4 \mathrm{~h}$ after access to feed with DNPME compared with CON as hypothesized. Additionally, DNPME treatment decreased eating rate as a result of the increased meal length. A longer meal length compared with CON suggests that a delay in the satiety signal occurred as hypothesized. Furthermore, the effects of DNPME appeared to be rapid because eating rate was significantly decreased during the first meal compared with CON. None of the other feeding behavior measurements differed between treatments. Lack of treatment effect on hunger and satiety ratio may be due to few meals being consumed over the short time period. 
Table 4. Effect of an intrajugular injection of $10 \mathrm{mg} / \mathrm{kg}$ of $\mathrm{BW}^{0.75}$ of 2,4-dinitrophenol methyl ether and propylene carbonate (DNPME) or propylene carbonate (control) on hepatic metabolites in dairy cows for experiment 1

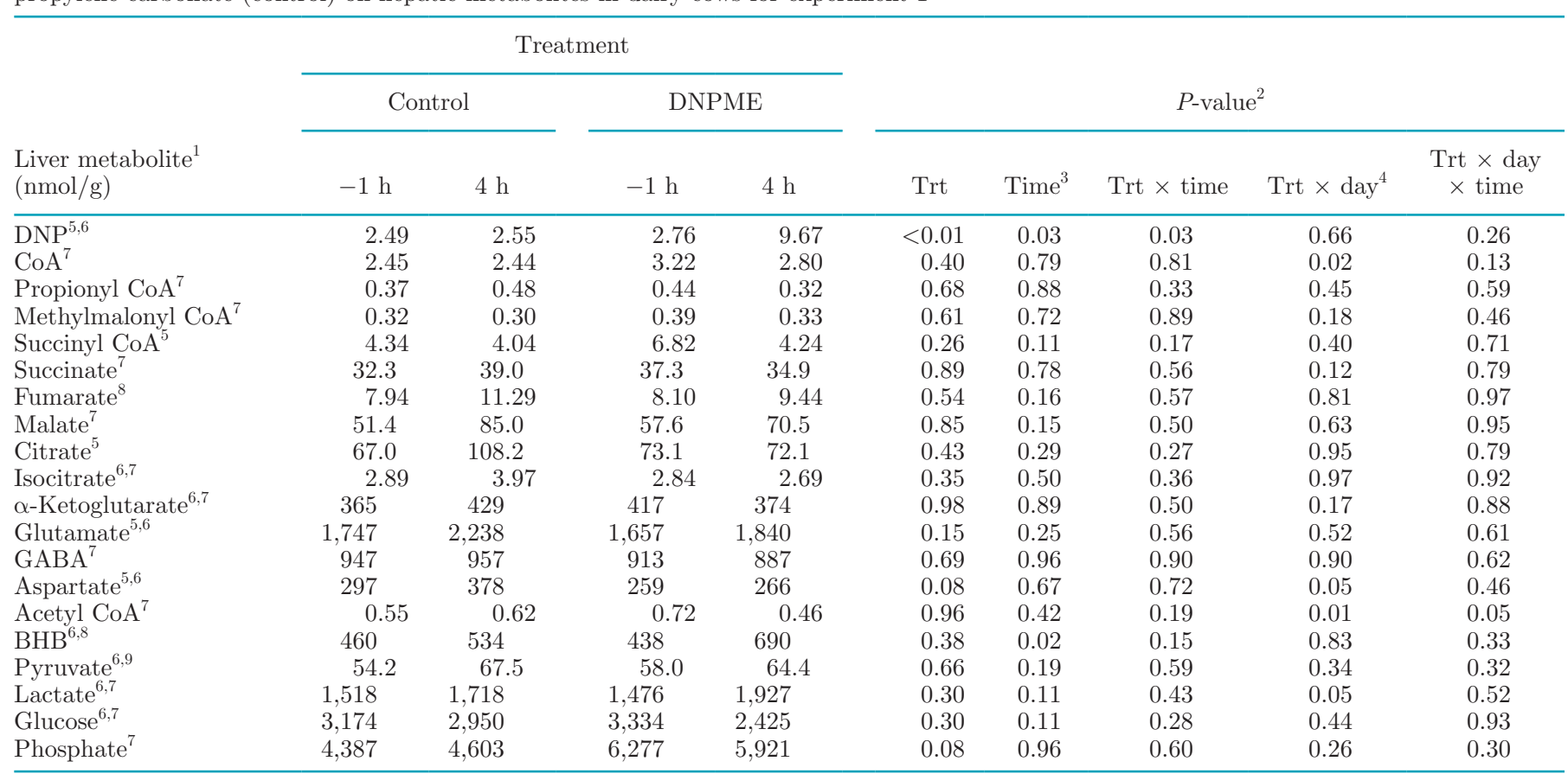

${ }^{1} \mathrm{DNP}=2,4$-dinitrophenol; CoA $=$ coenzyme A; GABA $=\gamma$-aminobutyric acid.

${ }^{2}$ Trt $=$ treatment; Time $=$ sampling time.

${ }^{3}$ Samples were taken -1 and $4 \mathrm{~h}$ relative to feed access.

${ }^{4}$ Each period in the crossover design consisted of $2 \mathrm{~d}$.

${ }^{5}$ Data were transformed using square root for statistical analysis and back-transformed for interpretation.

${ }^{6}$ Covariate $(-1 \mathrm{~h})$ was significant $(P<0.05)$.

${ }^{7}$ Data were log-transformed for statistical analysis and back-transformed for interpretation.

${ }^{8}$ Data were transformed using the inverse of the square root for statistical analysis and back-transformed for interpretation.

${ }^{9}$ Data were transformed using the reciprocal for statistical analysis and back-transformed for interpretation.

The amount of ATP produced per molecule of oxygen through the electron transport chain, referred to as the $\mathbf{P} / \mathrm{O}$ ratio, is protected despite variability within the short term (Brand et al., 1994). Because hepatic energy status is dependent on ATP, ADP, and AMP concentrations, the $\mathrm{P} / \mathrm{O}$ ratio is directly related. Uncouplers of OXPHOS, such as DNP and salicylate, effectively decrease the $\mathrm{P} / \mathrm{O}$ ratio (Miyahara and Karler, 1965; Katyare et al., 1971). Therefore, an increase in the oxidation of fuels is one method to maintain the $\mathrm{P} / \mathrm{O}$ ratio. A decrease in hepatic acetyl CoA concentration was observed on d 2, but no changes in plasma NEFA or hepatic or plasma BHB were observed, suggesting that oxidation of acetyl CoA had increased. Therefore, the increase in oxidation of fuels may have minimized the decrease in hepatic energy status that was anticipated with the DNPME treatment attenuating the expected effects of DNPME on feeding behavior. Additionally, the tendency for aspartate to decrease with DNPME compared with CON is likely because aspartate was catabolized to preserve the $\mathrm{P} / \mathrm{O}$ ratio. A tendency for an increase in MUN and tendency for a decrease in percentage milk fat compared with $\mathrm{CON}$ suggests that protein was metabolized and NEFA may be partitioned toward tissues other than the mammary gland, consistent with an increased oxidation of fuels. Although no treatment or treatment $\times$ time effects were detected for plasma metabolites, plasma glucose and NEFA concentrations decreased over time and hepatic and plasma BHB concentrations increased over time as expected (Allen, 2014).

We expected to see an increase in inorganic phosphate concentration because DNP liberates inorganic phosphate (Lardy and Wellman, 1953; Katyare et al., 1971). Although DNPME tended to increase inorganic phosphate concentration compared with $\mathrm{CON}$, this is misleading because the baseline values between DNPME and CON numerically differed and no treatment $\times$ time interactions were observed. The lack of change in inorganic phosphate over time suggests that 


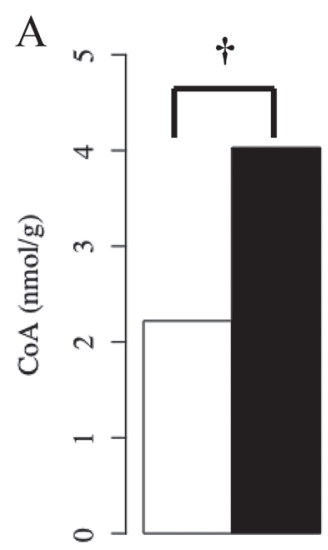

Day 1

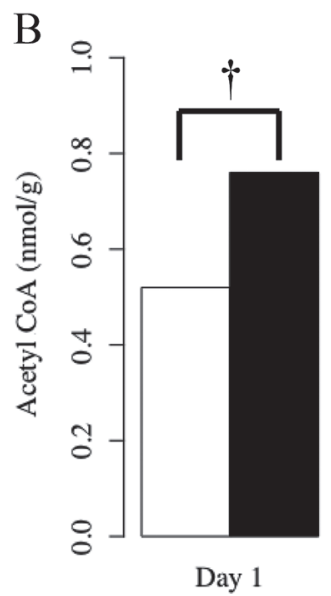

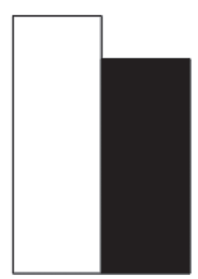

Day 2

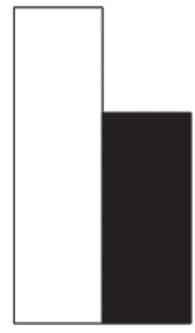

Day 2
$\mathrm{C}$

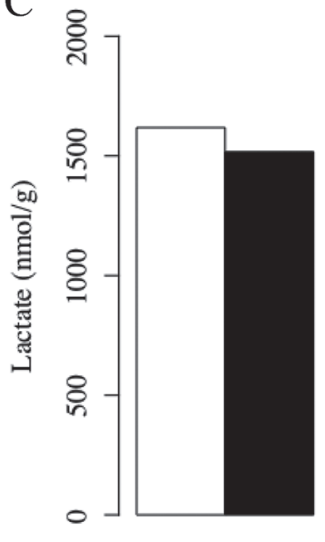

Day 1

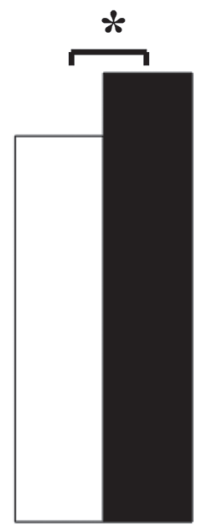

Day 2

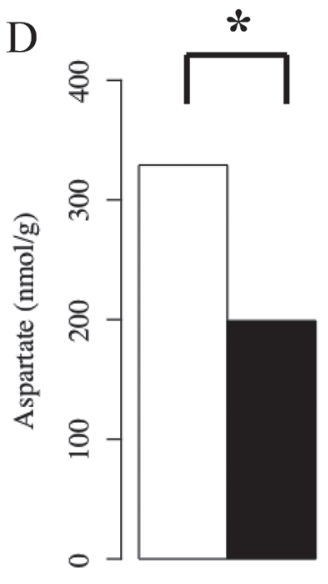

Day 1

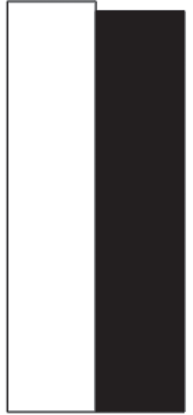

Day 2

Figure 2. Hepatic concentration (nmol/g) of (A) coenzyme A (CoA), (B) acetyl CoA, (C) lactate, and (D) aspartate on d 1 and 2 in dairy cows from experiment 1. Treatments were an intrajugular injection of $10 \mathrm{mg} / \mathrm{kg}$ of BW $\mathrm{BW}^{0.75}$ of 2,4-dinitrophenol methyl ether and propylene carbonate (DNPME; black) or propylene carbonate (control; white). The covariate $(-1 \mathrm{~h})$ was significant for lactate and aspartate $(P<0.05)$. Hepatic CoA, acetyl CoA, and lactate concentrations were log-transformed for statistical analysis and back-transformed for interpretation. Aspartate was transformed using the square root and back-transformed for interpretation. The DNPME treatment significantly differed between $\mathrm{d} 1$ and 2 for all metabolites $(P<0.05)$, and the control did not differ between d 1 and 2 for all metabolites $(P>0.15)$. Within-day differences are denoted by $*(P \leq 0.05)$ and tendencies are denoted by $\dagger(P \leq 0.10)$.

fuel oxidation increased to maintain energy charge or that the pool of inorganic phosphate was too large to detect changes.

Metabolic flexibility is generally defined as the ability to respond or adapt to changes in metabolic demand. Adipose tissue has been proposed to play a major role in this flexibility and act as a buffer by supplying circulating fatty acids (Storlien et al., 2004). The late-lactation cows in the experiment were in positive energy balance and expected to have an increased responsiveness to mobilize body reserves when met with an unexpected increase in energy demands compared with cows in the immediate PP period that are in a lipolytic state.

\section{Experiment 2}

The increase in salicylate concentration observed in the liver $4 \mathrm{~h}$ after access to feed confirmed that SAL had been absorbed by the liver. However, the half-life of salicylate is approximately $50 \mathrm{~min}$ in cattle (Short et al., 1991); therefore, by $4 \mathrm{~h}$, less than $1 / 16$ of the original concentration of salicylate likely remained. Treatment with SAL did not increase meal size or meal length over the first $4 \mathrm{~h}$ after access to feed as expected; however, eating rate decreased with SAL compared with CON. No other feeding behavior measurements differed between treatments over the first $4 \mathrm{~h}$ after access to feed 
and, as with experiment 1 , the hunger and satiety ratio may not have differed because of the short window of observation. Bertoni et al. (2004) administered acetyl-
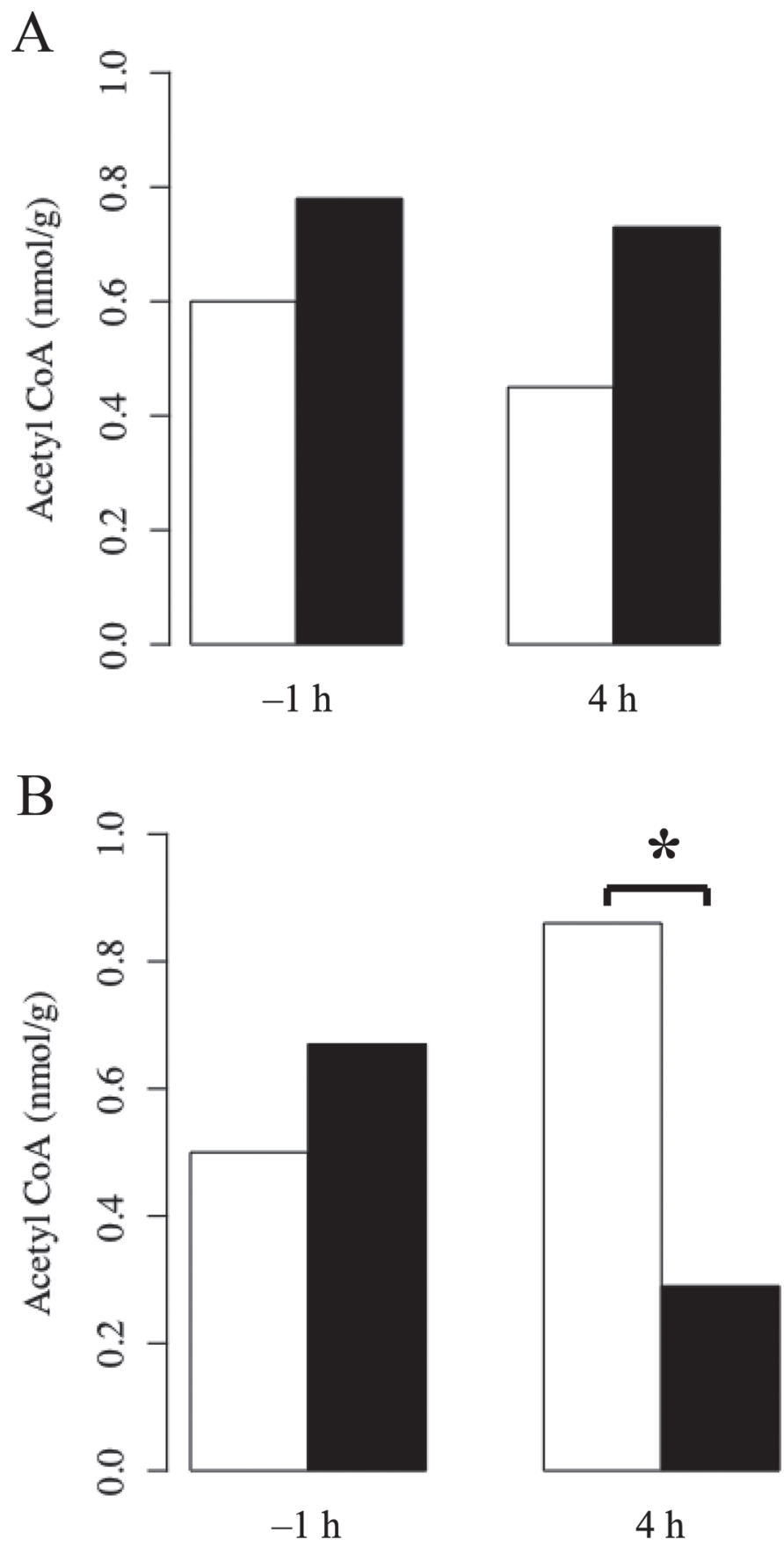

Figure 3. Hepatic concentration $(\mathrm{nmol} / \mathrm{g}$ ) of acetyl coenzyme A $(\mathrm{CoA})$ at -1 and $4 \mathrm{~h}$ relative to access to feed in dairy cows on (A) d 1 and (B) d 2 from experiment 1. Treatments were an intrajugular injection of $10 \mathrm{mg} / \mathrm{kg}$ of $\mathrm{BW}^{0.75}$ of 2,4-dinitrophenol methyl ether and propylene carbonate (DNPME; black) or propylene carbonate (control; white). Significant pairwise effects were detected only on d 2 . The DNPME treatment tended to decrease acetyl CoA concentration at 4 h compared with $-1 \mathrm{~h}(P=0.07)$. Data were log-transformed for statistical analysis and back-transformed for interpretation. Within-time differences between treatments are denoted by $*(P<0.05)$. salicylate intramuscularly and reported an increase in DMI, but oral administration of salicylate, which can inhibit rumen fermentation and digestion (Carpenter et al., 2017), failed to increase DMI when administered to dairy cows through drinking water for the first 7 DIM (Farney et al., 2013) or as a drench for the first 3 DIM (Carpenter et al., 2018). However, in the experiment reported by Carpenter et al. (2018), cows with parity $\geq 3$ had a delayed increase in meal size with salicylate treatment compared with control beginning at wk 10 of lactation, long after salicylate would likely affect feeding by hepatic oxidation.

The SAL treatment decreased yields of milk fat and protein and tended to decrease lactose yield in the morning, suggesting that compensatory oxidation of fuels may have occurred, diverting these components from milk production. However, Farney et al. (2013) observed that dairy cows treated with salicylate through drinking water for the first 7 DIM did not affect milk protein, fat, or lactose yield during the treatment period.

Salicylate inhibits the oxidation of succinate in liver mitochondria (Miyahara and Karler, 1965), and the conversion of succinate to fumarate in the tricarboxylic acid cycle is the second complex of the electron transport chain. A tendency for an increase in hepatic succinyl CoA concentration, the precursor to succinate, was observed with SAL compared with CON. An increase in succinyl CoA concentration may suggest that complex II of the electron transport chain was hindered by SAL. Additionally, an increase in hepatic acetyl CoA concentration, but no change in plasma and hepatic BHB concentration, was observed with SAL compared with CON. Therefore, excess acetyl CoA is likely not being converted to BHB. Although no change in plasma NEFA concentration was observed, an increase in oxidation of NEFA would result in an increase of the acetyl CoA pool. Additionally, succinyl CoA is a competitive inhibitor of citrate synthase (EC 2.3.3.1), specifically competing with acetyl CoA (Smith and Williamson, 1971). Citrate synthase is the enzyme responsible for converting acetyl $\mathrm{CoA}$ and oxaloacetate into citrate for oxidation through the tricarboxylic acid cycle. As such, the increased concentration of succinyl CoA may have prevented or delayed the reaction and contribute to the observed increased acetyl CoA concentration with SAL. Although no treatment or treatment $\times$ time effects were detected for plasma metabolites, plasma glucose and NEFA concentrations decreased over time and plasma BHB concentrations tended to increase over time, as would be expected from dairy cows consuming feed over time. Additionally, acetyl CoA concentrations decreased over time, which aligns with Piantoni et al. (2015), who reported a decrease in acetyl CoA concen- 
Table 5. Effect of an intrajugular injection of $50 \mathrm{mg} / \mathrm{kg}$ of BW of sodium salicylate and saline (SAL) or saline (control) on hepatic metabolites in dairy cows for experiment 2

\begin{tabular}{|c|c|c|c|c|c|c|c|}
\hline $\begin{array}{l}\text { Liver metabolite }{ }^{1} \\
(\mathrm{nmol} / \mathrm{g})\end{array}$ & \multicolumn{4}{|c|}{ Treatment } & & & \\
\hline Salicylate $^{4,5}$ & 13.8 & 12.6 & 12.8 & 19.9 & $<0.01$ & 0.03 & $<0.01$ \\
\hline $\mathrm{CoA}^{4,5}$ & 7.24 & 4.40 & 7.10 & 6.47 & 0.04 & 0.15 & 0.31 \\
\hline Propionyl $\mathrm{CoA}^{4}$ & 1.77 & 1.29 & 1.68 & 1.67 & 0.52 & 0.51 & 0.52 \\
\hline Succinate $^{4}$ & 77.7 & 76.3 & 78.4 & 72.5 & 0.84 & 0.67 & 0.79 \\
\hline Fumarate $^{6}$ & 49.7 & 49.8 & 50.4 & 44.3 & 0.25 & 0.18 & 0.18 \\
\hline Malate $^{7}$ & 155 & 159 & 159 & 134 & 0.50 & 0.59 & 0.46 \\
\hline Oxaloacetate $e^{5,6}$ & 3.50 & 3.14 & 3.55 & 2.93 & 0.36 & 0.02 & 0.46 \\
\hline Citrate $^{4,5}$ & 97.5 & 84.4 & 97.8 & 85.7 & 0.92 & 0.14 & 0.95 \\
\hline Isocitrate $^{5,8}$ & 35.9 & 33.0 & 35.9 & 31.8 & 0.37 & 0.01 & 0.59 \\
\hline$\alpha$-Ketoglutarate $e^{4,5}$ & 152 & 134 & 150 & 130 & 0.76 & 0.13 & 0.94 \\
\hline Pyruvate & 72.9 & 72.8 & 75.9 & 69.7 & 0.97 & 0.48 & 0.50 \\
\hline Lactate $^{7}$ & 452 & 465 & 405 & 779 & 0.29 & 0.10 & 0.12 \\
\hline Glucose $^{4,5}$ & 1,479 & 1,558 & 1,488 & 1,017 & 0.14 & 0.25 & 0.14 \\
\hline Phosphate $^{7}$ & 7,545 & 5,776 & 8,591 & 6,523 & 0.40 & 0.17 & 0.95 \\
\hline
\end{tabular}

${ }^{1} \mathrm{CoA}=$ coenzyme $\mathrm{A} ; \mathrm{GABA}=\gamma$-aminobutyric acid

${ }^{2}$ Trt $=$ treatment; Time $=$ sampling time.

${ }^{3}$ Samples were taken -1 and $4 \mathrm{~h}$ relative to feed access.

${ }^{4}$ Data were log-transformed for statistical analysis and back-transformed for interpretation.

${ }^{5}$ Covariate $(-1 \mathrm{~h})$ was significant $(P<0.05)$.

${ }^{6}$ Data were transformed using the reciprocal for statistical analysis and back-transformed for interpretation.

${ }^{7}$ Data were transformed using square root for statistical analysis and back-transformed for interpretation.

${ }^{8}$ Data were transformed using the inverse of the square root for statistical analysis and back-transformed for interpretation.

trations in dairy cows in the immediate PP period $4 \mathrm{~h}$ after feeding.

\section{Overall}

Metabolic mechanisms were assumed to be the dominant factors controlling feed intake of the cows in both experiments. Physiological state of the cows differed between the 2 experiments, and although not directly comparable, cows in both experiments responded to treatments designed to induce uncoupling of oxidative phosphorylation. The cows in experiment 2 in the immediate PP period had numerically greater hepatic acetyl CoA concentrations than the late-lactation cows in experiment 1 , which is in agreement with Piantoni et al. (2015), who reported that cows in the PP period had greater hepatic acetyl $\mathrm{CoA}$ concentrations compared with mid- to late-lactation cows. Alternative fuels to use for oxidation may not be as readily available in cows in the immediate PP period, so changes in hepatic energy status may be easier to induce. In addition, SAL is a less potent uncoupler of OXPHOS than DNP (Pen- niall, 1958). Therefore, the effects of DNPME on feeding behavior may be greater in cows that have a greater pool of hepatic acetyl CoA available for oxidation, and research examining the effects of DNPME on feeding behavior in cows in the immediate PP period should be conducted. In addition, future research needs to be done to determine the effects of DNPME and salicylate on ruminant hepatic tissue metabolism and respiration in the short term.

\section{CONCLUSIONS}

The uncouplers of OXPHOS used in this study failed to increase meal size or daily DMI, but both DNPME and salicylate decreased eating rate over the first $4 \mathrm{~h}$ of feeding, and DNPME increased meal length over the first $4 \mathrm{~h}$ of feeding. Lack of change in DMI and feeding behavior may have been caused by compensatory oxidation of fuels, but hepatic energy status was not measured. More research is needed to determine the short-term metabolic effects of uncouplers of OXPHOS on ruminant hepatic tissue and the effects of DNPME 
on feeding behavior of dairy cows in the immediate PP period.

\section{ACKNOWLEDGMENTS}

This work was supported by AFRI NIFA Fellowships Grant Program (2017-67011-26042/1010850) from the USDA National Institute of Food and Agriculture (Washington, DC). We also thank R. J. Tempelman for statistical advice; A. D. Jones, S. Smith, L. Chen, and A. Schilmiller for mass spectrometry training and advice; and D. G. Main, L. G. Duarte, R. Albornoz, G. Maldini, M. Bowers, A. Meade, and R. West (all from Michigan State University), as well as the staff of the Michigan State University Dairy Cattle Field Laboratory (East Lansing) and Michigan State University Mass Spectrometry and Metabolomics Core (East Lansing), for their assistance in this experiment.

\section{REFERENCES}

Allen, M. S. 2014. Drives and limits to feed intake in ruminants. Anim. Prod. Sci. 54:1513-1524. https://doi.org/10.1071/AN14478.

Allen, M. S., B. J. Bradford, and M. Oba. 2009. Board-invited review: The hepatic oxidation theory of the control of feed intake and its application to ruminants. J. Anim. Sci. 87:3317-3334. https://doi .org/10.2527/jas.2009-1779.

Allen, M. S., and P. Piantoni. 2013. Metabolic control of feed intake: Implications for metabolic disease of fresh cows. Vet. Clin. North Am. Food Anim. Pract. 29:279-297. https://doi.org/10.1016/j .cvfa.2013.04.001.

AOAC International. 1997. Official Methods of Analysis. 16th ed. AOAC International, Gaithersburg, MD.

Bertoni, G., E. Trevisi, and F. Piccioli-Cappelli. 2004. Effects of acetyl-salicylate used in post-calving of dairy cows. Vet. Res. Commun. 28:217-219.

Bradford, B. J., and M. S. Allen. 2005. Phlorizin administration increases hepatic gluconeogenic enzyme mRNA abundance but not feed intake in late-lactation dairy cows. J. Nutr. 135:2206-2211.

Brand, M. D., L. F. Chien, E. K. Ainscow, D. F. Rolfe, and R. K. Porter. 1994. The causes and functions of mitochondrial proton leak. Biochim. Biophys. Acta. 1187:132-139. https://doi.org/10.1016/ 0005-2728(94)90099-x.

Carpenter, A. J., C. V. Rodriguez, J. A. B. Jantz, and B. J. Bradford. 2017. Sodium salicylate negatively affects rumen fermentation in vitro and in situ. J. Dairy Sci. 100:1935-1939. https://doi.org/10 $.3168 /$ jds.2016-11832.

Carpenter, A. J., C. M. Ylioja, L. K. Mamedova, K. E. Olagaray, and B. J. Bradford. 2018. Effects of early postpartum sodium salicylate treatment on long-term milk, intake, and blood parameters of dairy cows. J. Dairy Sci. 101:1437-1447. https://doi.org/10.3168/ jds.2017-13057.

Dado, R. G., and M. S. Allen. 1995. Intake limitations, feeding behavior, and rumen function of cows challenged with rumen fill from dietary fiber or inert bulk. J. Dairy Sci. 78:118-133. https://doi .org/10.3168/jds.S0022-0302(95)76622-X.

Farney, J. K., L. K. Mamedova, J. F. Coetzee, B. KuKanich, L. M. Sordillo, S. K. Stoakes, J. E. Minton, L. C. Hollis, and B. J. Bradford. 2013. Anti-inflammatory salicylate treatment alters the metabolic adaptations to lactation in dairy cattle. Am. J. Physiol. Regul. Integr. Comp. Physiol. 305:R110-R117. https://doi.org/10 .1152 /ajpregu.00152.2013.
Forbes, J. M. 2007. A personal view of how ruminant animals control their intake and choice of food: Minimal total discomfort. Nutr. Res. Rev. 20:132-146. https://doi.org/10.1017/S0954422407797834.

Friedman, M. I., R. B. Harris, H. Ji, I. Ramirez, and M. G. Tordoff. 1999. Fatty acid oxidation affects food intake by altering hepatic energy status. Am. J. Physiol. 276:R1046-R1053. https://doi.org/ 10.1152/ajpregu.1999.276.4.R1046.

Grundlingh, J., P. I. Dargan, M. El-Zanfaly, and D. M. Wood. 2011. 2,4-dinitrophenol (DNP): A weight loss agent with significant acute toxicity and risk of death. J. Med. Toxicol. 7:205-212. https: //doi.org/10.1007/s13181-011-0162-6.

Hoch, F. L., and F. P. Hogan. 1973. Hyperthermia, muscle rigidity and uncoupling in skeletal muscle mitochondria in rats treated with halothane and 2,4-dinitrophenol. Anesthesiology 38:237-243.

Ji, H., G. Graczyk-Milbrandt, and M. I. Friedman. 2000. Metabolic inhibitors synergistically decrease hepatic energy status and increase food intake. Am. J. Physiol. Regul. Integr. Comp. Physiol. 278:R1579-R1582. https://doi.org/10.1152/ajpregu.2000.278.6 R1579.

Katyare, S. S., P. Fatterpaker, and A. Sreenivasan. 1971. Effect of 2 4-dinitrophenol (DNP) on oxidative phosphorylation in rat liver mitochondria. Arch. Biochem. Biophys. 144:209-215.

Kennedy, K. M., and M. S. Allen. 2019. Hepatic metabolism of propionate relative to meals for cows in the postpartum period. J. Dairy Sci. https://doi.org/10.3168/jds.2018-15907.

Lardy, H. A., and H. Wellman. 1953. The catalytic effect of 2,4-dinitrophenol on adenosine triphosphate hydrolysis by cell particles and soluble enzymes. J. Biol. Chem. 201:357-370.

Miyahara, J. T., and R. Karler. 1965. Effect of salicylate on oxidative phosphorylation and respiration of mitochondrial fragments. Biochem. J. 97:194-198.

Penniall, R. 1958. The effects of salicylic acid on the respiratory activity of mitochondria. Biochim. Biophys. Acta. 30:247-251. https:// doi.org/10.1016/0006-3002(58)90047-7.

Perry, R. J., T. Kim, X. M. Zhang, H. Y. Lee, D. Pesta, V. B. Popov, D. Zhang, Y. Rahimi, M. J. Jurczak, G. W. Cline, D. A. Spiegel, and G. I. Shulman. 2013. Reversal of hypertriglyceridemia, fatty liver disease, and insulin resistance by a liver-targeted mitochondrial uncoupler. Cell Metab. 18:740-748. https://doi.org/10.1016/ j.cmet.2013.10.004.

Piantoni, P., C. M. Ylioja, and M. S. Allen. 2015. Feed intake is related to changes in plasma nonesterified fatty acid concentration and hepatic acetyl CoA content following feeding in lactating dairy cows. J. Dairy Sci. 98:6839-6847. https://doi.org/10.3168/jds.2014 -9085 .

Rawson, N. E., H. Blum, M. D. Osbakken, and M. I. Friedman. 1994. Hepatic phosphate trapping, decreased ATP, and increased feeding after 2,5-anhydro-D-mannitol. Am. J. Physiol. 266:R112-R117. https://doi.org/10.1152/ajpregu.1994.266.1.R112.

Short, C. R., C. A. Neff-Davis, L. C. Hsieh, G. D. Koritz, M. S. Malbrough, S. A. Barker, and L. E. Davis. 1991. Pharmacokinetics and elimination of salicylic acid in rabbits. J. Vet. Pharmacol Ther. 14:70-77. https://doi.org/10.1111/j.1365-2885.1991.tb00806 .x.

Smith, C. M., and J. R. Williamson. 1971. Inhibition of citrate synthase by succinyl-CoA and other metabolites. FEBS Lett. 18:3538 .

Storlien, L., N. D. Oakes, and D. E. Kelley. 2004. Metabolic flexibility. Proc. Nutr. Soc. 63:363-368. https://doi.org/10.1079/ PNS2004349.

Toyomizu, M., K. Okamoto, M. Tanaka, and T. Ishibashi. 1992. Research note: Effect of 2,4-dinitrophenol on growth and body composition of broilers. Poult. Sci. 71:1096-1100. https://doi.org/10 $.3382 / \mathrm{ps} .0711096$.

USEPA (US Environmental Protection Agency). 1980. Ambient water quality criteria for nitrophenols. EPA 440/5-80-063. USEPA Washington, DC 


\section{APPENDIX}

Table A1. Effect of an intrajugular injection of $10 \mathrm{mg} / \mathrm{kg}$ of $\mathrm{BW}^{0.75}$ of 2,4-dinitrophenol methyl ether and propylene carbonate (DNPME) or propylene carbonate (control) on milk yield and milk components in dairy cows for experiment 1

\begin{tabular}{|c|c|c|c|c|c|}
\hline \multirow[b]{2}{*}{ Milk analyte $^{1}$} & \multicolumn{2}{|c|}{ Treatment } & \multicolumn{3}{|c|}{$P$-value } \\
\hline & Control & DNPME & Treatment & Day $^{2}$ & Treatment $x$ day \\
\hline \multicolumn{6}{|l|}{ p.m. samples } \\
\hline Yield $^{3,4}(\mathrm{~kg})$ & 13.4 & 13.9 & 0.42 & 0.10 & 0.34 \\
\hline $\mathrm{Fat}^{3}(\%)$ & 4.16 & 3.89 & 0.10 & 0.89 & 0.37 \\
\hline Fat yield ${ }^{3}(\mathrm{~kg})$ & 0.56 & 0.54 & 0.60 & 0.27 & 0.35 \\
\hline Protein $^{3}(\%)$ & 3.37 & 3.33 & 0.47 & 0.61 & 0.72 \\
\hline Protein yield ${ }^{3,4}(\mathrm{~kg})$ & 0.45 & 0.46 & 0.49 & 0.11 & 0.33 \\
\hline Lactose (\%) & 4.60 & 4.54 & 0.14 & 0.02 & 0.93 \\
\hline Lactose yield ${ }^{3,4}(\mathrm{~kg})$ & 0.62 & 0.63 & 0.68 & 0.29 & 0.36 \\
\hline Solids (\%) & 5.45 & 5.38 & 0.19 & 0.02 & 0.93 \\
\hline Solids yield ${ }^{3,4}(\mathrm{~kg})$ & 0.73 & 0.74 & 0.66 & 0.31 & 0.36 \\
\hline MUN (mg/dL) & 17.0 & 17.7 & 0.37 & 0.67 & 0.27 \\
\hline MUN (g) & 2.19 & 2.45 & 0.10 & 0.08 & 0.20 \\
\hline \multicolumn{6}{|l|}{ a.m. samples } \\
\hline Yield (kg) & 16.9 & 16.7 & 0.83 & 0.53 & 0.21 \\
\hline $\mathrm{Fat}^{3,4}(\%)$ & 3.33 & 3.54 & 0.18 & 0.14 & 0.17 \\
\hline Fat yield ${ }^{4}(\mathrm{~kg})$ & 0.59 & 0.61 & 0.58 & 0.26 & 0.93 \\
\hline Protein $^{3}(\%)$ & 3.44 & 3.36 & 0.02 & 0.60 & 0.43 \\
\hline Protein yield (kg) & 0.59 & 0.56 & 0.32 & 0.51 & 0.20 \\
\hline Lactose $(\%)$ & 4.65 & 4.61 & 0.19 & 0.48 & 0.47 \\
\hline Lactose yield (kg) & 0.79 & 0.77 & 0.56 & 0.62 & 0.28 \\
\hline Solids (\%) & 5.54 & 5.51 & 0.24 & 0.19 & 0.61 \\
\hline Solids yield $(\mathrm{kg})$ & 0.94 & 0.92 & 0.55 & 0.66 & 0.26 \\
\hline MUN (mg/dL) & 15.9 & 17.1 & 0.21 & 0.79 & 0.54 \\
\hline $\operatorname{MUN}^{5}(\mathrm{~g})$ & 2.58 & 2.80 & 0.56 & 0.80 & 0.40 \\
\hline
\end{tabular}

${ }^{1}$ Samples were taken at the first milking after treatment (p.m.) and at the second milking after treatment (a.m.).

${ }^{2}$ Each period in the crossover design consisted of $2 \mathrm{~d}$.

${ }^{3}$ Data were transformed using the reciprocal for statistical analysis and back-transformed for interpretation purposes.

${ }^{4}$ Covariate (p.m. and a.m. samples taken $1 \mathrm{~d}$ before the start of the experiment) was significant $(P<0.05)$.

${ }^{5}$ Data were log-transformed for statistical analysis and back-transformed for interpretation purposes. 
Table A2. Effect of an intrajugular injection of $50 \mathrm{mg} / \mathrm{kg}$ of BW of sodium salicylate and saline (SAL) or saline (control) on milk yield and milk components in dairy cows for experiment 2

\begin{tabular}{|c|c|c|c|}
\hline \multirow[b]{2}{*}{ Milk analyte ${ }^{1,2}$} & \multicolumn{2}{|c|}{ Treatment } & \multirow{2}{*}{$\frac{P \text {-value }}{\text { Treatment }}$} \\
\hline & Control & SAL & \\
\hline \multicolumn{4}{|l|}{ p.m. samples } \\
\hline Yield (kg) & 18.8 & 17.8 & 0.26 \\
\hline Fat $(\%)$ & 4.68 & 4.51 & 0.20 \\
\hline Fat yield (kg) & 1.44 & 1.29 & 0.20 \\
\hline Protein (\%) & 3.22 & 3.19 & 0.62 \\
\hline Protein yield ${ }^{3}(\mathrm{~kg})$ & 0.82 & 0.75 & 0.17 \\
\hline Lactose (\%) & 4.76 & 4.83 & 0.19 \\
\hline Lactose yield $^{3}(\mathrm{~kg})$ & 1.22 & 1.13 & 0.17 \\
\hline Solids (\%) & 5.22 & 5.43 & 0.32 \\
\hline Solids yield ${ }^{3}(\mathrm{~kg})$ & 1.30 & 1.21 & 0.22 \\
\hline $\operatorname{MUN}^{3}(\mathrm{mg} / \mathrm{dL})$ & 13.1 & 13.1 & 0.90 \\
\hline MUN (g) & 2.56 & 2.30 & 0.19 \\
\hline \multicolumn{4}{|l|}{ a.m. samples } \\
\hline Yield (kg) & 22.7 & 20.6 & 0.07 \\
\hline Fat $(\%)$ & 4.06 & 4.05 & 0.98 \\
\hline Fat yield (kg) & 1.49 & 1.32 & 0.05 \\
\hline Protein $(\%)$ & 3.21 & 3.19 & 0.69 \\
\hline Protein yield ${ }^{3}(\mathrm{~kg})$ & 0.99 & 0.88 & 0.05 \\
\hline Lactose (\%) & 4.84 & 4.87 & 0.59 \\
\hline Lactose yield $^{3}(\mathrm{~kg})$ & 1.48 & 1.33 & 0.10 \\
\hline Solids $(\%)$ & 5.37 & 5.40 & 0.61 \\
\hline Solids yield ${ }^{3}(\mathrm{~kg})$ & 1.57 & 1.43 & 0.11 \\
\hline MUN (mg/dL) & 13.8 & 14.1 & 0.70 \\
\hline MUN $(\mathrm{g})$ & 3.03 & 2.84 & 0.25 \\
\hline
\end{tabular}

${ }^{1}$ Samples were taken at the first milking after treatment (p.m.) and at the second milking after treatment (a.m.).

${ }^{2}$ Covariate (p.m. and a.m. samples taken $1 \mathrm{~d}$ before the start of the experiment) was significant for all milk analytes except fat yield for the p.m. samples and for all milk analytes for the a.m. samples $(P<0.05)$. ${ }^{3}$ Data were transformed using the reciprocal for statistical analysis and back-transformed for interpretation purposes.

Table A3. Effect of an intrajugular injection of $10 \mathrm{mg} / \mathrm{kg}$ of BW ${ }^{0.75}$ of 2,4-dinitrophenol methyl ether and propylene carbonate (DNPME) or propylene carbonate (control) on plasma metabolites and hormones in dairy cows for experiment 1

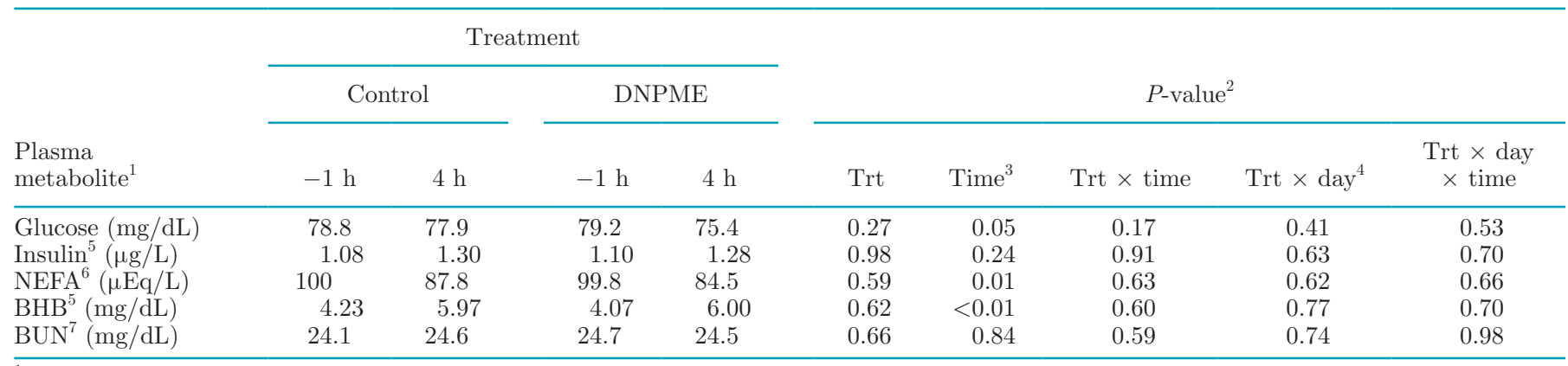

${ }^{1}$ Covariate $(-1 \mathrm{~h})$ was significant all for metabolites $(P<0.05)$.

${ }^{2}$ Trt $=$ treatment; Time $=$ sampling time.

${ }^{3}$ Samples were taken -1 and $4 \mathrm{~h}$ relative to feed access.

${ }^{4}$ Each period in the crossover design consisted of $2 \mathrm{~d}$.

${ }^{5}$ Data were log-transformed for statistical analysis and back-transformed for interpretation purposes.

${ }^{6} \mathrm{NEFA}=$ nonesterified fatty acids. Data were transformed using the inverse of the square root for statistical analysis and back-transformed for interpretation purposes.

${ }^{7}$ Data were transformed using the reciprocal for statistical analysis and back-transformed for interpretation purposes. 
Table A4. Effect of an intrajugular injection of $50 \mathrm{mg} / \mathrm{kg}$ of BW of sodium salicylate and saline (SAL) or saline (control) on plasma metabolites and hormones in dairy cows for experiment 2

Treatment

\begin{tabular}{|c|c|c|c|c|c|c|}
\hline \multicolumn{2}{|c|}{ Control } & \multicolumn{2}{|c|}{ SAL } & \multicolumn{3}{|c|}{$P$-value ${ }^{2}$} \\
\hline$-1 \mathrm{~h}$ & $4 \mathrm{~h}$ & $-1 \mathrm{~h}$ & $4 \mathrm{~h}$ & Trt & Time $^{3}$ & Trt $\times$ time \\
\hline 54.2 & 49.4 & 54.2 & 50.6 & 0.36 & $<0.01$ & 0.56 \\
\hline 0.17 & 0.21 & 0.17 & 0.23 & 0.64 & 0.13 & 0.59 \\
\hline 601 & 402 & 612 & 339 & 0.35 & $<0.01$ & 0.30 \\
\hline 14.4 & 16.8 & 14.4 & 14.9 & 0.33 & 0.10 & 0.31 \\
\hline 21.6 & 22.2 & 21.9 & 20.7 & 0.13 & 0.64 & 0.18 \\
\hline
\end{tabular}

${ }^{1}$ Covariate $(-1 \mathrm{~h})$ was significant for all metabolites $(P<0.05)$.

${ }^{2}$ Trt $=$ treatment; Time $=$ sampling time.

${ }^{3}$ Samples were taken -1 and $4 \mathrm{~h}$ relative to feed access.

${ }^{4}$ Data were transformed using the inverse of the square root for statistical analysis and back-transformed for interpretation purposes.

${ }^{5}$ Nonesterified fatty acids.

${ }^{6}$ Data were log-transformed for statistical analysis and back-transformed for interpretation purposes.

${ }^{7}$ Data were transformed using the reciprocal for statistical analysis and back-transformed for interpretation purposes. 